\title{
Limits of Environmental Understanding: Action and Constraint
}

\author{
James G. Carrier
}

The natural environment is where we live, and its condition has been the focus of increasingly vocal concern for approximately 40 years. In addition, a growing body of social scientists have begun to ask how people construe and think about their environment, and their physical surroundings more generally.

For instance, some have considered the ways that people culturally convert a patch of their surroundings from an abstract space into a place endowed with meaning, affect, and history (e.g. A.Gupta and J.Ferguson 1997). So, Michèle Dominy (2000) has described how sheep farmers in the highlands of New Zealand's South Island interact with their surroundings as a part of their pastoralism. This work results in an understanding that marks the land with the history of the people and activities associated with it, and with the activities associated with the present-day people who occupy and work the land. In her descriptions of Australian Aboriginals and cattle ranchers in North Queensland, Veronica Strang (1997) describes broadly similar processes.

In his introduction to an influential collection on the anthropology of landscape, Eric Hirsch (1995) takes a somewhat different approach. He argues that landscape, which includes the natural environment, is best seen in relationship to a foreground, to which that landscape is background. Moreover, he suggests that the landscape background is commonly understood as a realm of potential, the locus of a vision of the way things might be; the foreground, on the other hand, is present reality. In his interpretation, then, landscape is often construed as a commentary on the present and a goal to which people aspire.

For my purposes, this concern with meaning is manifest most pertinently in work that specifically addresses the question of how people think about what in the West is called "nature." Two writers who are especially influential in this area are Tim Ingold and Arturo Escobar.

Ingold's basic approach distinguishes two broad views of the natural environment. In one of his earlier formulations (1993:35), he calls these the "sphere" and "globe" views: "[T]he lifeworld, imagined from an experiential centre, is spherical in form, whereas a world divorced from life, that is yet complete in itself, is imagined in the form of a globe." Those with a sphere view see themselves as being enmeshed in their surroundings, springing from their close practical engagement with it. Such people do not distinguish the cultural and the natural realms in any very clear way, and see the world as a sphere in which they and their practical activities occupy the centre. Macnaghten and Urry (1998:167) summarize this perspective: "Landscape is the world as known to those who have dwelt there, who do dwell there, who will dwell there, and those whose practical activities take them through its manifold sites and who journey along its multitudinous paths."

Those with a globe view, on the other hand, see themselves as being distinct from their surroundings. Such people draw a distinction between the natural on the one hand, and the social and cultural on the other. They see the world as a globe, outside of which they stand and which they observe at a distance, so that their environment is a construction of 
contemplation rather than practical engagement. Such people "can describe their environment, and report on their actions within it, as though they had themselves stepped outside it, posing as mere spectators" (Ingold 1992:52). This resembles the conception of the surroundings that Macnaghten and Urry (1998:1) call "environmental realism", a conception that sees the environment as "essentially a 'real entity'... substantially separate from social practices and human experience."

A clear and accessible statement of Escobar's position is presented in a recent article (1999). Like Ingold, he seeks to make the concept "nature" problematic, arguing that, around the world, there are three general "regimes of nature," sorts of views of the natural environment: organic nature, capitalist nature, and techno nature. Organic nature is characterized by "the fact that nature and society are not separated ontologically" (A.Escobar 1999:7), so that there is no clear separation of "the biophysical [i.e., "natural"], human, and supernatural world" (A.Escobar 1999:8). This resembles Ingold's sphere orientation. Escobar says there is a range of manifestations of such organic views of nature among peasant and village societies, but they spring from a practical engagement with the natural environs. Capitalist nature's core is the objectification of "nature" linked to the spread of patriarchal capitalism and the commodity form. This produces an alienated view of the environment, apprehended through the mechanisms of capitalist rationality and control (A.Escobar 1999:6). This resembles Ingold's globe orientation. Finally, Escobar's techno nature is a regime that is only now emerging, so his discussion of it is only tentative. In this regime, the boundary between nature and culture is blurred through such things as genetic engineering (A.Escobar 1999:11-12). While the boundary may be blurred, the approach to the natural environment is mediated by Modern technologies and developments, and hence indirectly by the drive for profit that motivates so many of them. To a degree, then, this regime also resembles Ingold's globe view, because the natural is subject to greater and more intimate domination by objectifying human knowledge.

These writers illustrate an important thread within anthropology: a concern with the ways that people think about their surroundings, and especially the natural environment. Their concern with meaning and understanding reflects the predominance within anthropology late in the twentieth century of a broadly cultural orientation, associated with scholars like Clifford Geertz and Marilyn Strathern. Even though this cultural orientation has led to interesting and stimulating work, it has, however, an important limitation ${ }^{1}$ that becomes apparent when we ask ourselves a question: Just what have we learned when we learn how people understand their environs? Of course we have learned how people think. People also act in the world, however, and at times they act selfconsciously and intentionally concerning their environs, regardless of how those environs might be understood. The limitation of these culturalist approaches is that they tend to ignore the actions that spring from those understandings.

These writers do not ignore action. Indeed, for many of them it is an important focus. For instance, in her discussion of high country New Zealand sheep farmers, Dominy devotes substantial space to farming practices, just as Strang attends to the practices of the Queensland Aboriginals and cattle ranchers that she describes. Ingold is very much concerned with action, reflecting the concern with bodily practice that is part of his

1. For a consideration of this predominance in a different area of anthropology, and a consideration of its limitations there, see Carrier and Heyman (1997). 
phenomenological orientation (e.g. 1988, 1990, 1998). For Escobar, different ways of acting in the world are implicit in the three regimes of nature that he describes. Even so, that incorporation of action seems to be only partial. That is, these writers focus on people's action as the foundation of their understandings of their environs. I have no argument with this. Whether these writers intend it or not, however, their underlying models tend to consider action only as a cause of people's views of the natural environment, and tend to ignore it as a consequence, or consider it a relatively unproblematic reflection of those views.

In doing this, these writers tend to ignore the ways that people can be constrained by factors that make their actions a distorted or imperfect expression of those understandings, and the ways that these constraints might then engender other, additional views of the natural environment. Thus they make it harder to see the point that Barbara Bender (1998: 34) makes, that "landscapes_-even as experienced by a single person — are multiple and contradictory." That link between intention and action is my concern here. I want to get at that link by looking at some of the people associated with two national parks in Jamaica, at Montego Bay and Negril. Both parks were authorized by the Jamaican government in the 1990s.

Creating each of these parks was a complex process, requiring extensive agitation to secure support at the local, national, and even international levels. Influential local people, members of parliament and government officials and scientists had to be turned into supporters. $^{2}$ Although many people were involved, each park had a core of activists that was relatively stable throughout the 1990s. For each park, however, there were one or two central figures, leaders commonly seen as driving the move toward establishment. These central figures are my main focus here. ${ }^{3}$ I use them to illustrate the sorts of factors that can constrain people when they act on the basis of their understandings of the natural environment. The factors that will concern me are broadly economic and politicaleconomic, though I will also consider a political-social factor, the local fishers whose access to fish these parks restrict.

Before considering these central activists, I should clarify the limitations of this paper. First, my concern is these activists and their understandings, and I treat the parks only as background. Their operation is of importance only to the extent that they help us to understand these activists and the situations and constraints that they confront. Second, I present these cases with only a modest aim, to illustrate the ways that some people's

2. Park managers and activists in both locations were concerned about the weak knowledge of and support for the parks and their management policies among local populations, and especially local fishers.

3. The literature on environmental activists is less central to the anthropology of the environment than is the sort of work I describe in these opening paragraphs. A significant thread within that work reflects the influence of Mary Douglas's model of grid and group, transmuted in her work on risk (M.Douglas and A.Wildavsky 1982; see, e.g., U.Beck 1992), and seeks to account for why some people become concerned about the state of the environment, and the sort of actions that they advocate. Like the work I have described, this thread takes a broadly culturalist orientation. There is other work that considers activists and their actions (e.g. E.Berglund 1998). However, this work tends to be more concerned with understanding the beliefs and strategies of activists than with considering constraints upon those actions. 
understandings of their environs may reflect processes and forces that are more complex than the culturalist construction of the Modernist view may allow.

\section{Activists and Understandings}

In this section I describe three activists who were driving forces behind these parks. The sorts of processes illustrated in these descriptions, however, were fairly common among the activists that I dealt with and got to know in Montego Bay and Negril, as well as other places in Jamaica. ${ }^{4}$ Most of them have lived in Jamaica for decades, having gone there from Europe and the United States, and they have thoroughly Modern backgrounds. They include an engineer, an IT (Information Technology) specialist, a person who had worked in advertising, a person trained as a nurse, and others. These people have been instrumental in different ways in establishing the two national parks: the Montego Bay Marine Park and the Negril Marine Park.

\section{Negril}

The Negril Marine Park was declared by the Jamaican government in 1998. It was the result of agitation by the Negril Coral Reef Preservation Society (NCRPS). There had been precursor organizations, but the NCRPS itself was established in 1990. It is a conservationist organization originally dominated by a small number of Europeans and North Americans who were locally active in commerce in general, and the tourism industry in particular. Two women were influential in the NCRPS, and through it were instrumental in the formal establishment of the Negril park. I will call these women X and Y, both from the United States and both born around 1950. X was effectively the founder of the NCRPS and was long its president; $\mathrm{Y}$ was a close friend of $\mathrm{X}$ and also served as president. Their understandings of the environment contrast in interesting ways.

X's conception of the environment is centred on the coastal waters in the immediate area of Negril. She sees these waters as being in an increasingly unhealthy state, which she sees as being both caused by and manifest in the deterioration of the coral. One of her recurrent concerns is the shrinking of Negril's sandy beach, which she sees as being caused by that deterioration.

One aspect of X's approach to the marine environment is scientific. She is by no means a specialist, but she is knowledgeable about coral and how it relates to the coastal environment. She is equally knowledgeable about the science of coastal ecosystems, especially about the effects of terrestrial runoff, which appear to be important in Negril. Overall, then, she is concerned with the coastal ecosystem as a whole. (Her approach is not universally accepted among marine biologists who have worked in Jamaican waters; it is effectively that presented in T.Goreau et al. 1997).

Although one aspect of her approach to the marine environment is scientific, her approach also reflects the events of her personal life. To understand how she thinks of the environment, then, it is necessary to understand what brought this American woman to Negril, and what she did once she arrived.

4. I dealt with these people directly and by e-mail starting in 1997, as part of my work as supervisor of the social anthropology side of a research project on marine conservation in the Caribbean. This side of the project looked only at Jamaica. 
In the 1970s, X was living in the United States. After a serious illness and divorce, she saw some pictures of Negril, and decided to go there to recover from her illness and the subsequent collapse of her marriage. When she first moved to Negril, she did not work for about five years.

During this period she swam several miles each day, up and down the shore of the area of Negril called the West End. She was not exploring the coastal waters, for her route did not vary. Instead, as she described it, she was passing her days, recovering from the disastrous events that had befallen her, gradually rebuilding herself physically and mentally. She was doing this in the context of one particular part of the environment, which became implicated in her personal recovery and reconstruction. She told me stories of her delight at seeing octopuses changing colour and how she got to know what she described as the personalities of different sorts of marine life. This experience would account for the affective, clearly and strongly emotional way that X views Negril's environmental degradation. This is an emotion that she saw in others as well. For example, she told me how she showed local people photographs of the Negril beach in the 1950s, when she says it was about 100 yards wide (currently it is perhaps 10-15 yards in many places). She said older fishermen cried when they saw how much worse things had become. This affective involvement led her to take a closer interest in the marine environment, and to search out books and knowledgeable people.

After she used up her money, she ended up working for Y, who had been her landlady. Y owned a dive shop in Negril, a small business that rented and refilled air tanks, taught people how to dive, and provided boats to take people out diving. $X$ volunteered, to assist her friend and to earn some money. She was quickly trained, first as a diver and then as an instructor. As she became more concerned about the marine environment, she recruited $\mathrm{Y}$ to her cause.

X's case shows how a Modern, Western person can acquire a close personal identification with the environment of the sort that does not appear to accord with Ingold's globe view or Escobar's capitalist nature, but instead resembles the emotional, personal identification described by Kay Milton (2002: Chap. 4). This identification and its affective element spring from the vagaries of X's personal life; the waters off the West End, and the marine life she saw there, took on a distinctive meaning for her because they were interwoven in the way she rebuilt herself after she left the United States. X's personal engagement was consequential, for it was an essential factor in the establishment of the Negril Marine Park.

Y's approach to the Negril coastal waters is very different. Although she likes diving, Y is not emotionally involved in diving or coastal waters as $\mathrm{X}$ is. Rather, $\mathrm{Y}$ is a woman who enjoys running her own business, and that business happens to be a dive shop that happens to be in Negril. She enjoys dealing with people, she enjoys working with her staff, she enjoys the organization of the business, she enjoys turning a scared novice into someone who can dive and enjoy it. It is not too much of an exaggeration to say that, for Y, the Negril coastal waters are simply the background in which she pursues the activities that she enjoys and that provide her livelihood. Like X, Y swims at Negril, but unlike X whose swimming was an emotional, personal process of recovery, Y swims as part of her work, for the exercise, or to get from point A to point B.

$\mathrm{Y}$ is aware of the deterioration of the marine environment in Negril and is concerned about it. Her concern, however, is rather abstract and impersonal. She showed none of the sense of fervor or emotional engagement that X showed. Y said that she did not get involved with the NCRPS and become one of its leading officers out of conservationist 
concern. Rather, she did so because she was a friend of $\mathrm{X}$ and wanted to support her, and because she enjoyed the administrative side of the job.

These two women are close friends, and both are involved in the same conservationist organization. They illustrate very different approaches to the environment, however. Indeed, I have described Y because she is such a marked contrast to X. Where X's approach to the marine environment is personal and affective, Y's is more clearly instrumental. Because $\mathrm{Y}$ ran a dive shop, one might expect that she has a practical engagement with the marine environment, the waters where her customers dived. She could, in other words, resemble Strang's or Dominy's pastoralists. Y, however, showed no signs of this. Instead, the waters were simply where she carried out the work that she enjoyed; her interest and engagement were with the work, not the place where she did it.

\section{Montego Bay}

In its present form, the Montego Bay Marine Park is the result of agitation by the Montego Bay Marine Park Trust. This organization was dominated by a dozen or fewer Europeans who moved to Montego Bay at various times in the past few decades. The Trust was formally established after a small marine park was set up in Montego Bay in the 1970s. Not only do the Montego Bay park and the Trust have a longer history than the Negril park and the NCRPS, but agitation for a marine conservation area in Montego Bay appears to have been more of a collective affair than was the case with Negril. Many of those involved, however, said that one man, here called $\mathrm{Z}$, was the most important early force.

For Z, as for X, "the environment" is effectively the marine environment, here the waters of Montego Bay. He is aware of scientific findings about Montego Bay and has worked with marine biologists in Jamaica. Like X, however, he is no scientist. Also like X, he said that much of the cause of the deterioration of the bay is land based. He referred to dredging and other alterations to the beach front in the 1970s, a part of the extraordinary growth of Montego Bay as a tourist area in the last third of the twentieth century. He also referred to changes in the runoff going into the bay as a result of the clearing of forest and the spread of farms in the area. Yet again like X, Z's scientific orientation is only one aspect of his approach to the environment. The other important aspect springs from his personal history. This is less striking than X's, but still is important in personal terms and consequential in institutional terms.

Z first went to Jamaica in 1957, to Kingston. In 1964, he transferred to Montego Bay and formed a diver's group with two others, one of whom ran a dive shop at a hotel. Around 1970, $\mathrm{Z}$ and his fellows learned that a group of British divers too large to be accommodated by the existing dive organizations wanted to go to Montego Bay. They decided to form their own company to cater to visiting divers. Forming this company clearly was a commercial decision, but not purely commercial. Patently, $\mathrm{Z}$ enjoyed Montego Bay as a place to dive, took pride in it, and wanted others to enjoy it as well.

The pride and pleasure were undermined, however. Around the time that $\mathrm{Z}$ and his fellows set up their dive company, the editor of a popular American diving magazine wrote that he had noticed that the waters of Montego Bay were not as clear as they had been. Z and his fellows decided that the editor was correct. As a result, they held a workshop around 1974 to try to address the problem. This led to a proposal for a marine protected area, relatively small, in Montego Bay. This was officially recognized by the Jamaican government late in 1974 (P.O’Callaghan, J.Woodley, and K.Aiken 1988). 
It is clear that Z's involvement with the marine environment in Montego Bay was less personal than was X's in Negril. Z was recovering from no personal crisis in the midst of Montego Bay's waters. One element of Z's involvement was diving as a commercial enterprise, rather like X's friend Y. Such an involvement would seem to mark Z as having a globe-like or capitalist orientation. After all, for $\mathrm{Z}$ the marine environment effectively was, among other things, a commodity that Z's company sold to tourist divers. It is also clear, however, that this does not capture Z's thinking adequately.

Z's commercial interest both sprang from and fed his involvement with the marine environment. As I have said, $\mathrm{Z}$ formed his dive company partly out of his pleasure and pride in diving in Montego Bay. Equally, the pragmatics of running the dive company formed a context within which $\mathrm{Z}$ engaged practically with aspects of his environment. This was not the engagement of Strang's or Dominy's pastoralists, but it was a practical engagement nonetheless, reflected in things like the workshop around 1974 and Z's repeated involvement with efforts to protect and improve the bay's waters. Because $\mathrm{Z}$ was living in Montego Bay and diving in its waters for so many years, he was likely to see those waters as figuring in important events in his life (although X's friend Y shows that this is by no means necessary.) For instance, around 1970 two of Z's friends tried to set personal depth records; neither came back. Eventually both bodies were recovered, one from a depth of over 300 feet. Not surprisingly, Z said that this helped to change the way he thought about the waters at Montego Bay.

Although Z lacked X's intense personal engagement with the marine environment, his engagement was not simply utilitarian. He took a personal interest in the state of the waters of Montego Bay and in what people said about it. So, Z was proud of the way that his early dive business enabled visitors from the British Isles to swim and enjoy a body of water in which Z took a proprietary interest. Similarly, he was unsettled by the reaction of the editor of the American diving magazine to the waters of Montego Bay, and unhappy when he recalled his own growing sense that the quality of the waters noticeably deteriorated around 1970. Montego Bay was part of his world and work, and what affected it affected him, both professionally and personally.

\section{Activists' Understandings}

I have presented the background associated with the formation of these marine parks in Jamaica to show the personal, affective ways that $\mathrm{X}$ and $\mathrm{Z}$ viewed their natural environment. For them, the coastal waters are not something they stand apart from; or, rather, this is not all the coastal waters are. $\mathrm{X}$ and $\mathrm{Z}$ are reasonably familiar and comfortable with an environmentalist and marine-biological approach: Macnaghten and Urry"s "environmental realism"(1998). But this coexists with another approach, one in which important aspects of X's and Z's lives bear the mark of their relationship with their respective coastal waters. $\mathrm{X}$ articulated this link more than $\mathrm{Z}$, but for both the link is there.

$X$ 's tale clearly is unusual, and although Z's tale lacks the personal crisis that $X$ underwent, Z's experience and interaction with the coastal waters are also unusual. This is, perhaps, not very surprising. After all, both of these people are themselves unusual, devoting years of their lives to environmental activism, culminating in each case with the establishment of a national park. Although the case studies I have presented here are too few to prove anything, they do suggest that it may be reasonable to think that people who are influential environmental activists are prone to see their environment in the "wrong" 
way, wrong according to Ingold's and Escobar's models: not at a distance, but as enmeshed in their lives.

These models make it difficult to see that if a person has important experiences in the context of a particular environment, then it is reasonable to anticipate that the experiences and the environment will inflect each other, and so jointly inflect that person's selfconception and life. Of course such a person may have a Modernist, distanced, globe-like conception of "the environment," as X and Z had. Such a person, however, also could have a much more intimate and sphere-like conception of "this environment," the concrete environs that are the context of those experiences. X's case, rare though it may be, illustrates this clearly; Z's case illustrates it as well.

\section{Realizing Understandings}

Thus far I have sketched the ways that some of the key activists in Negril and Montego Bay understood the natural environment. I said that $\mathrm{X}$ and $\mathrm{Z}$ had multiple understandings, both personal-affective and scientific, the former being the basis for the latter and for acting to bring about a marine protection regime. In expanding their understandings of the natural environment, they also expanded their perspectives on the environment. $\mathrm{X}$ and $\mathrm{Z}$ had a personal and affective relationship with this environment, specific parts of Jamaica's coastal waters that had featured in important parts of their lives. When they began to acquire a scientific understanding of the environment, they began to complement their understanding of a concrete geographical area, a place, with a more abstract understanding (see generally J.Carrier 2001b). When they acquired this new understanding, they acquired an orientation that treated Negril and Montego Bay more purely as space, as locations where general environmental processes could be seen to be at work.

In this acquisition we can see signs of the sorts of external factors that might constrain people when they act in ways that reflect their understandings of their surroundings. With regard to $\mathrm{X}$ and $\mathrm{Z}$, their affective and personal relationship with a place, this environment, led them to be concerned about the state of those waters. The main legitimate way that this concern could be expanded and furthered was for them to acquire an orientation that, although useful and even necessary, required that they look at those waters in a radically different way. This orientation ignored (and in its scientific rationality could even be said to denigrate) the sort of affect and relationship to a specific place that were important for motivating $\mathrm{X}$ and $\mathrm{Z}$ in the first place.

Although this was one of the constraints on these people as they sought to realize their understandings of the environment, it was certainly not the only one, nor was it one that bothered them very much. The constraints that did bother them, and that bothered many others concerned with environmental protection in Jamaica, were those that they encountered when they came into contact with another environment. Their practical engagement with that environment affected them in important ways.

That environment is one populated by the institutions that are pertinent for people who want to establish conservation organizations. For $\mathrm{X}$ and $\mathrm{Z}$, these institutions included the Jamaican state in its administrative and legislative forms: government agencies and bureaucratic office-holders, members of parliament, and government ministers. They also included NGOs and national and supranational agencies in Jamaica and elsewhere. For conservationists in Jamaica, the most noteworthy of these was the United States Agency for International Development (the USAID). 
These institutions were insistently important for those involved in establishing the Negril and Montego Bay parks for one overwhelming reason, the political-economic ideology that goes under the name of neoliberalism. This ideology is based on an idealization of the free market (see J.Carrier 1997), and is expressed as a kind of virtualism, efforts by powerful institutions to make the world conform to the virtual reality defined by that idealization (see J.Carrier and D.Miller 1998). ${ }^{5}$

Perhaps the core of neoliberalism is a radical rejection of the state and of the commonality that the state is supposed to represent or embody. This rejection has two important elements: a rejection of the state as a political entity and a rejection of the state as an economic entity. The rejection of the state as a political entity is manifest as a declining faith in the efficacy of state agencies and a growing faith in local institutions and organizations, i.e. "the community" (A.Etzioni 1993; see also M.Moore 1993). Central governments are seen as corrupt, or at least lethargic, grossly inefficient, and unresponsive; local groups are seen as energetic and efficient. In terms of conservation, this means a growing stress on participatory or community conservation, part of a rhetoric of "empowering" people (see J,Adams and T.McShane 1996;W.Adams and D.Hulme 1998; P.Christie and A.White 1997; M.Leach and R.Mearns 1996; E.Roe 1991). The rejection of the state as an economic entity is manifest as a growing pressure to curtail state financial power and regulation. Especially for poorer countries like Jamaica, this is also associated with a loss in the legitimacy of state-based models of economic development and the rise of market-based models (see D.Bromley 1994; P.McMichael 1998; J.Toye 1993).

In Jamaica, these two strands of neoliberalism exist in the Natural Resource Conservation Authority, which until the early 1990s was the Natural Resource Conservation Department, the central government agency that oversaw environmental and conservation projects. The shift from "Department" to "Authority," largely in response to pressure from the USAID, was a shift from government agency to quasi-autonomous organization, an effort to take conservation out of the political hands of the state and put it in the putatively nonpolitical hands of local activists and specialists. ${ }^{6}$ The neoliberal policy of the NRCA and its justification were summarized by some environmental activists:

5. The most visible agent of this virtualism has been the International Monetary Fund (IMF), and the most notorious vehicle has been structural adjustment regimes. Like other countries in the Caribbean, Jamaica has been subject to such regimes. Structural adjustment regimes are developed for countries in complex ways, apparently as much political (even party-political) as economic or political-economic (for Jamaica and other Caribbean countries see C.Edie 1991). Although Jamaica rejected IMF regimes late in the 1990s, the effect of this rejection has been insignificant in terms of state policies. This is because that rejection was not accompanied by any marked reversal of earlier IMF-induced policy changes, and because Jamaica was seeking to be included in the North American Free Trade Agreement, which obliged the state to keep IMF-type policies in place.

6. Although the NRCA was supposed to be relatively independent, in fact it was a creature of the USAID, which, for some years, occupied the top floor of the building in Kingston where the NRCA was housed and which was involved in extensive guidance and training of NRCA staff under the development rubric of "capacity building." 
The Natural Resources Conservation Authority (NRCA)... recognizes that officials in the capital are less able than locally based organizations to identify local problems, propose solutions, or implement them. Central control over environmental policy has historically resulted in decisions favouring short term financial interests of individuals and institutions which are well connected in the capital. Decision making is often protracted and may not address local concerns. Residents of the area feel increasingly dispossessed and powerless to control access to resources or halt degradation from development that adversely affects their quality of life, causing increasing alienation from the political process. NRCA has decided to increase the power of local communities to decide which forms of development, conservation, and environmental management best meet their long term needs [A.Goreau et al. 1997: 2093].

This judgement that local interests and organizations should be responsible for establishing conservation programmes is the political side of neoliberalism in Jamaica and elsewhere. The economic side is that local interests and organizations should be responsible for finding the money for those programmes. So, while the NRCA continues to disburse money to parks in Jamaica, the amount dropped sharply in line with sharp cuts in the NRCA budget in the last few years of the 1990s. For the Montego Bay park, NRCA funding fell from \$2.7 million Jamaican dollars in 1997 and 1998 (about \$75,000 US), to $\$ 450,000$ Jamaican dollars (about $\$ 12,000$ US) in 1999 and 2000, supplemented by about $\$ 125,000$ Jamaican dollars (about \$3,000 US) from an NRCA fund based on user fees collected at all installations the NRCA oversees - which is about a quarter of what the NRCA collected at the Montego Bay park [J. Williams, personal communication 2001].

The Negril and Montego Bay parks have had to secure their own funding. The dominant topic in two meetings of a Montego Bay park governing body in 1999 was raising money, and it was a recurrent theme in both the academic and the more purely social interactions I had with those involved in these two parks. The parks have pursued two different but related avenues in their search for money. One is international donors, the other is charging people, directly or indirectly, to enter the parks. For environmentalist organizations in Jamaica, the main international donor has been the USAID. ${ }^{7}$

Dealing with the USAID obliged these organizations and the senior people involved in them to understand and present themselves in distinctive ways, though any substantial donor would likely expect the same sort of self-presentation. This meant construing these parks as bureaucratic, rational organizations. The concrete form this took was the annual development of management plans and business plans by the last part of the 1990s. The 1998 management plan for the Montego Bay park (Montego Bay Marine Park 1998) is around 70 pages. It begins with plan goals, followed by statements of the park's mission and vision, and contains a set of action plans. The vast majority of the management plan is a set of five action plans, each with a set of associated "strategies," themselves containing a set of "activities": "Marine ecosystem management," "User management," "Community relations," "Administration," and "Financial sustainability." The Negril management plan for 1998 is broadly comparable, though twice as long.

7. Negril got money from the European Union (EU), but the EU's presence in conservation in Jamaica is much smaller than that of the USAID. 
The logic behind management plans seems reasonable in principle. It makes sense to encourage people to think through just what it is that they want to do. At the same time, such plans oblige people to socialize their desire and motivations, to translate them into a particular language that is socially powerful (see J.Carrier 1997:47-54, 2001a). The management plan for the Negril park could not begin with X's illness, divorce, and years spent swimming off the West End; the management plan for the Montego Bay park could not refer to people who died trying to set depth records, or even to Z's pride in helping divers enjoy the bay's waters. Preparing these plans obliges these activists to silence, and hence deny, their personal histories, histories in which local waters played an important part. Rather, it obliges them to think of themselves and their goals in terms of things like biodiversity, ecosystem, consultative groups, and the like. And this obligation, which is a part of these people's practical engagement with their institutional environment, can be expected to affect the ways that they think about and engage with their marine environment, now an object of administrative planning as well as personal history and scientific knowledge.

I said that the other avenue for securing funding is charging people to enter or benefit from the parks; in effect, attracting ecotourists. This is not a new idea, and it is an attractive one. For instance, estimates for the number of ecotourists in the world from as long ago as 1988 range between 157 and 236 million; estimates for the revenue they generated ranged up to about 1.2 trillion US dollars (H.Ceballos-Lascurain 1996:46-8). In the Caribbean, ecotourists provide substantial income for some marine parks. $\mathrm{X}$ and $\mathrm{Z}$, and others involved in these two parks, were told repeatedly of places like Saba Marine Park and Bonnaire Marine Park (see J.Dixon et al. 1993), both in the Netherlands Antilles, where fees charged to divers generated substantial income and even financial independence (for detailed analyses, see R.Framhein 1995 for Saba, and L.Scura and T. van't Hof 1993 for Bonnaire).

Ecotourism was attractive to Jamaica for another reason. Partly as a result of increasing international pressure for open markets (another aspect of neoliberalism), local industries were deteriorating, agriculture was increasingly uncertain as an export sector, and the national economy increasingly relied on tourism to generate foreign exchange. Thus, in 1994 (Statistical Institute of Jamaica 1996:318, 331), total exports of domestic goods were roughly 39 billion Jamaican dollars whereas foreign travel receipts, effectively earnings from tourism, were about 30 billion Jamaican dollars. But while Jamaica increasingly relied on tourism, its position in the tourist market and the benefits it gained from tourism were deteriorating. Like most Caribbean tourism, Jamaican tourism was in a commodity sector selling sun, sand, and sea, items available not only throughout most of the Caribbean but also throughout most of the tropical world. As a result, the industry in Jamaica had become dominated by all-inclusive resorts competing on price for the largely North American tourist market. The result was fewer linkages with the Jamaican economy and increasing domination by large corporations (see P.Pattulo 1996).

Ecotourism was generally thought to attract tourists who were wealthier than mass tourists and less sensitive to price. The commercial and state revenue that ecotourism could generate looked tempting. For example, Dixon, Scura and van't Hof (1993) argue that the recreational use of the Virgin Islands National Park in the early 1980s brought benefits totalling 23.3 million US dollars annually (this ignores social and political drawbacks; see K.Olwig 1980). Tobago's Buccoo Reef and Bon Accord Lagoon Restricted Area are said to have brought approximately 510,000 US dollars in revenues per year (T.van't Hof 1985:554), and the use of Bonaire Marine Park is thought to have 
generated annual revenues of over 23 million US dollars which is nearly half the island's entire income (L.Scura and T.van't Hof 1993: 37-9).

Ecotourism was an important element of a study of possible sites for marine parks in Jamaica carried out late in the 1980s, and it was an important reason why Montego Bay was selected as a site, even though some had argued that efforts would be better devoted to establishing a park in an area that was less degraded and that could be effectively protected with the limited resources likely to be available. After all, Montego Bay was and remains the prime tourist location in Jamaica. In the late 1990s it was the country's second largest city, with 56 hotels and over 5,000 rooms (L.Bunce and K.Gustavson 1998:75). The report on possible park locations in Jamaica made the obvious point:

marine parks can be pretty much self-supporting through a number of activities: snorkeling, SCUBA diving, glass bottom boat tours arranged for a fee. Usually the marine park organization will leave most of these activities to commercial diver operators and watersport centers. In that case, however, substantial revenues may be obtained from concessions.... If basically all commercial activities in a marine park are subject to permits, then a variety of activities can be hired out to concessionaires (P.O'Callaghan et al. 1988: 37).

So, these parks are obliged to present themselves not just as bureaucratic, rational organizations, but as bureaucratic, rational, commercial organizations. In line with this, it is appropriate that of the five action plans in the Montego Bay park 1998 management plan, the longest is the fifth, "Financial sustainability." The goal of that plan is: "To become financially sustainable through utilizing all possible sources of revenue, cost sharing and partnerships including fees, donations, grants, volunteerism and sales of goods and services, locally, nationally and internationally, from private, corporate, government and institutional organizations." The associated substrategies are: a visitor centre at the park headquarters, an ecotourism programme, merchandising and franchising, generating park products and services, placing collection boxes in the area, corporate fund-raising, setting up a donor organization, user permits, holding public events, participating in existing public events, and establishing a park trust fund.

The political-economic environment effectively put pressure on activists and managers to embrace ecotourism out of financial necessity. And this in turn affected the ways that people like $\mathrm{X}$, and the successors to $\mathrm{Z}$ in Montego Bay, thought about park waters, which is to say the ways that they understood their marine environment. At the most obvious level, these people were constrained to see that environment and the things in it in terms of a commodity, access to which was to be traded for money, Escobar's capitalist nature. For instance, $\mathrm{X}$ reported that hotel operators in Negril wanted her to ban all fishing in park waters. They said that their guests were complaining about the presence of Jamaicans in small fishing boats in park waters, believing that any fishing was bad for the marine environment, and apparently believing that no Jamaican fishing boat had a legitimate reason to be in park waters. From what X said, hotel operators seemed to agree. Two points are worth noting here. First, the Negril Park has not banned all fishing in all its waters. Second, access to the Negril town landing beach is through park waters, so that fishermen necessarily traverse those waters on their way elsewhere. $X$ resented this pressure from hotel operators. She saw it as a real constraint, however, springing from commercial interests, one that affected the ways that she saw the marine environment. 
More subtly, Montego Bay senior park management were interested in shaping park waters in ways that would attract ecotourists and convince hotel operators and others that it was worth paying access fees. This required the sort of accommodation that $\mathrm{X}$ was being obliged to make in Negril. Management wants to know about consumer demand: What is it that divers, a particularly salient body of ecotourists, are looking for in a dive site? Finally, some of the activists in Montego Bay made a frank link between tourism, money, and the environment. W, an activist with a substantial history of involvement in conservation organizations in Jamaica, made the point bluntly. The tourist industry should pay a levy for environmental protection. He said that their situation is "Just like in any business. It [the environment] is a maintenance cost."

I do not mean that people like $\mathrm{X}, \mathrm{Z}, \mathrm{W}$ and the rest responded to the pressures of their institutional environment by seeing the marine environment only in commodity terms. They did not. Rather, their earlier understandings of the environs were supplemented by an understanding of the environment as commodity, just as X's early and intensely personal understanding of Negril coastal waters was supplemented by the scientific orientation that she acquired subsequently. These pressures from the institutional environment were real constraints, however, and activists complained about them frequently, often in the form of stories about the USAID and the iniquities and idiocies of its policies and projects (for similar tales from elsewhere in the Caribbean, see B.Nietschmann 1995). Thus, the very institutional environment that these people confronted when they sought to protect their natural environment shaped their views of that environment and, in important ways, made it harder for them to achieve the goals that sprang from their initial understandings of and relationships with the coastal waters of Negril and Montego Bay.

\section{Practical Consequences}

In the preceding section, I described the sorts of institutional pressures that came to bear on these activists, and led them to accommodate themselves to and even adopt additional understandings of the coastal waters of Negril and Montego Bay. Here, I examine another apparent consequence of those pressures, their effects on local fishing people. These people are important both because their use of the coastal waters is restricted by these parks, and because their cooperation is important for successful marine conservation: the truism is that fisheries management will be only as good as the fishers allow it to be.

Local fishers were not some primordial, indigenous group. It is true that some were the children of fishers. To a significant extent, however, and particularly in Montego Bay, local fishers were a creature of Jamaica's economic position. The country's growing reliance on tourism was manifest in the way that Montego Bay turned into a boom town, and to a lesser extent the same happened in Negril. Because of this and the decline of older sections of the Jamaican economy, a large number of people moved to these locations to look for work. For those unable to find or keep jobs, fishing was a way of generating a bit of food and money. Such people were most likely to become spear fishers, for this technique could be learned easily and required little initial outlay.

The relationship between fishers and the parks was problematic, particularly because the parks' need to generate income and support from the tourist industry led to the accommodation to and association with the tourist industry that I have already mentioned. This had consequences, primarily negative ones, for the ways that local fishing people saw the parks. 
Both in terms of common perception and in reality, a key way that these two parks seek to preserve the coastal waters is by restricting fishing. Neither park banned fishing altogether, but both promulgated zone systems. These are regulations that divide park waters into different areas, and prohibit different activities (including types of fishing) within some of these areas. For these sorts of restrictions to be effective, the parks require either a massive and oppressive policing effort, which they do not want and cannot afford, or the cooperation of fishers. This sort of cooperation, however, is made less likely by the link between these parks and tourism (the following paragraphs draw on N.Polunin et al. 2000: esp. 55-64).

The aspect of the marine environment of the greatest practical concern to fishers is fish stocks, and fishers in these two locations agreed readily that stocks deteriorated markedly in the past. They also agreed that their fishing harmed these stocks. They dissented strongly, however, from the conservationist message and policy of these parks. The most straightforward basis of this dissent springs from their understanding of the causes of the deterioration of the marine environment. Although these fishers said that their fishing harmed fish stocks, they argued that their predation was a relatively minor influence, compared to the systematic degradation of that environment. As noted above, both $\mathrm{X}$ and $\mathrm{Z}$ also thought that environmental degradation was important.

The case is clearest in Montego Bay. Fishers there argued that the growth of the city, and the nature of the tourist industry that has fed that growth, were the main causes of the deterioration of coastal waters. I have already noted the large number of hotels in Montego Bay, a number that is increasing. The population of the city has grown sharply as well. One activist says that from about 1970 to the end of the 1990s, the city grew from about 25,000 people to about 125,000 (see also P.Bacon 1987:105; a smaller-scale version of this elsewhere in the Caribbean is described in S.McMinn and E.Cater 1998: 689-91).

The building of these hotels and the growth of the city led to the destruction of a substantial portion of the shoreline, as well as a number of large and environmentally beneficial mangrove stands. Another important factor that fishers mentioned is the construction of a new port facility in the bay in the 1970s. This was necessitated by the increased volume of shipping required to supply the growing city, as well as the desire to attract more and larger cruise ships. Building this port facility meant significant dredging and land filling very near an important and environmentally sensitive area of the bay, the Bogue Lagoon. Also, both to attract and to cater to tourists and commercial interests, a section of the bay was filled in and a portion of the shoreline modified near the centre of the city. In addition to this construction, fishers argued that the large tourist hotels continue to damage the marine environment. Some fishers, and at least one environmental specialist, said that it is likely that some of the beach-front hotels dump their sewerage directly into the bay, rather than processing it themselves or introducing it into the city's sewerage system.

Fishers, then, argued that while they were being asked to give up their fishing, nothing was being done about the main cause of the deterioration of the marine environment, the tourist industry. This not only struck them as unjust, it also reaffirmed the belief that these two parks were not so much about improving the coastal waters for everyone who used them, as they were about benefiting the tourist industry. The real association with and accommodation to the tourist industry by these two parks, necessitated ultimately by the institutional environment, was, then, a particular liability in the eyes of these fishers. 


\section{Conclusion}

I started by describing a culturalist orientation within anthropological work on the environment, a thread that seeks to describe and account for the way that people understand their natural environment. Those with this orientation have produced work that is interesting and provocative, but the orientation also has limitations. In particular, it tends to ignore the possibility that people's understandings of and actions regarding their natural surroundings may be in a generative, dialectical relationship with each other. This ignored possibility has been my concern here.

I have sought to address this possibility by looking at the ways that a few people in Jamaica had relationships with and understandings of their environs that led them to try to protect those environs, in actions that expressed those relationships and understandings. Those actions had consequences, however, for they brought these people into contact with a new environment, an institutional environment of state and foreign organizations and agencies, themselves shaped by the prevailing political economy of neoliberalism. Their efforts to deal with that new environment confronted those people with new constraints. Among these, I have pointed particularly to the need to supplement their initial personal and affective understandings with a more abstract and impersonal scientific understanding, and the need to construe coastal waters in bureaucratic and commercial terms.

These constraints affected the ways that these people construed and understood things, as they affected other activists in Jamaica. In addition, they affected these people's abilities to realize their initial environmentalist goals. Most obviously, the need to conform to the dictates of the USAID and the Jamaican government decreased the distance between these parks and the tourist industry as it increased the distance between the parks and local fishers, and so made it more difficult for them to gain their support. In addition, and more subtly, the need to accommodate to the constraining factors that confronted them has led to a shift in attention, away from their conservationist goals and toward satisfying the requirements of the pertinent institutions that they confront. One result not described here is marked disaffection. $\mathrm{X}$, for instance, had serious doubts about whether she or Negril had gained anything when the government proclaimed the park there.

The case studies presented here describe only a handful of people, people who are, moreover, distinctive in their activism and in the institutional consequences of their activism. These case studies were not described to prove anything, but to suggest that the culturalist orientation when applied to people's understandings of the environment may have shortcomings. For these people, and for others, the relationship among their understandings of the environment, their actions, and the outcomes of those actions, all are more problematic than is suggested by the culturalist model.

\section{Acknowledgements}

Some of the research referred to here was carried out as part of Overseas Development Administration (later Department for International Development) project R6783, "Ecological and social impacts in planning Caribbean marine-reserves," which ran from 1997 to 1999 . Among those I spoke with in Jamaica, I thank particularly Jill Williams and Jeremy Woodley, as well as Gordon Glave, Malden Miller and Teo Schmidt, and of course the anonymous $\mathrm{W}, \mathrm{X}, \mathrm{Y}$ and $\mathrm{Z}$. In the midst of their own busy lives, all these people were forthcoming and hospitable in ways for which I am most grateful. I am also grateful for the helpful comments on earlier versions of aspects of this by Kay Milton and Dimitrios Theodossopoulos, as well as the helpful comments of anonymous Journal readers. 


\section{References}

Adams, J. S. and T. McShane

1996. The Myth of Wild Africa. Berkeley: University of California Press.

Adams, W. M. and D. Hulme

1998. Conservation and Communities: Changing Narratives, Policies and Practices in African Conservation. (Working Paper No. 4.) Manchester: University of Manchester Institute of Development Policy and Management.

Bacon, P. R.

1987. Use of Wetlands for Tourism in the Insular Caribbean. Annals of Tourism Research 14: 104-117.

Beck, U.

1992. Rick Society: Towards a New Modernity. London: Sage.

Bender, B.

1998. Stonehenge: Making Space. Oxford: Berg.

Berglund, E.

1998. Knowing Nature, Knowing Science: An Ethnography of Environmental Activism. Cambridge: White Horse Press.

Bromley, D.

1994. Economic Dimensions of Community-Based Conservation. In Natural Connections. D. Western and M. Wright editors. Washington: Island Press, pp. 428447.

Bunce, L. and K. Gustavson

1998. Coral Reef Valuation: A Rapid Socioeconomic Assessment of Fishing, Watersports, and Hotel Operations in the Montego Bay Marine Park, Jamaica and an Analysis of Reef Management Implications. Report, Project RPO 681-05. Washington, DC: World Bank.

Carrier, J. G.

1997. Introduction. In Meanings of the Market: The Free Market in Western Culture. J. Carrier editor. Oxford: Berg, pp. 1-67.

2001a. Diplomacy and Indirection, Constraint and Authority. In An Anthropology of Indirect Communication. J. Hendry and B. Watson editors. London: Routledge, pp. 290-301.

2001b. Social Aspects of Abstraction. Social Analysis 9: 239-252.

Carrier, J. G. and J. McC. Heyman

1997. Consumption and Political Economy. Journal of the Royal Anthropological Institute 2: 355-373.

Carrier, J. G. and D. Miller (editors)

1998. Virtualism: A New Political Economy. Oxford: Berg.

Ceballos-Lascurain, $\mathrm{H}$.

1996. Tourism, Ecotourism and Protected Areas: The State of Nature-Based Tourism Around the World and Guidelines for its Development. Based on papers presented at the IV World Congress on National Parks and Protected Areas, Caracas 1992. Gland, Switzerland, and Cambridge: IUCN.

Christie, P. and A. T. White

1997. Trends in Development of Coastal Area Management in Tropical Countries: From Central to Community Orientation. Coastal Management 25: 155-81. 
Dixon, J. A., L. F. Scura, and T. van't Hof

1993. Meeting Ecological and Economic Goals: Marine Parks in the Caribbean. Ambio 22 (2-3): 117-25.

Dominy, M.

2000. Calling the Station Home: Place and Identity in New Zealand's High Country. Lanham, Md: Rowman and Littlefield.

Douglas, M. and A. Wildavsky

1982. Risk and Culture: An Essay in the Selection of Technical and Environmental Dangers. Berkeley: University of California Press.

Edie, C. J.

1991. Democracy by Default: Dependency and Clientelism in Jamaica. Boulder, Col.: Lynne Rienner / Kingston, Jamaica: Ian Randle.

Escobar, A.

1999. After Nature: Steps to an Antiessentialist Political Ecology. Current Anthropology 40: 1-30.

Etzioni, A.

1993. The Spirit of Community. New York: Fontana.

Framhein, R.

1995. The Value of Nature Protection: Economic Analysis of the Saba Marine Park. Summary for the Government of Saba, September.

Goreau, T. J., L. Daley, S. Ciappara, J. Brown, S. Bourke, and K. Thacker

1997. Community-Based Whole-Watershed and Coastal Zone Management in Jamaica. Proceedings of the Eighth International Coral Reef Symposium 2: 2093 2096.

Gupta, A. and J. Ferguson (editors)

1997. Culture, Power, Place. Durham, NC: Duke University Press.

Hirsch, E.

1995. Introduction: Landscape-Between Place and Space. In The Anthropology of Landscape: Perspectives on Place and Space. E. Hirsch and M. O'Hanlon editors.

Oxford: Oxford University Press, pp. 1-30.

Ingold, T.

1988. Tools, Minds and Machines: An Excursion in the Philosophy of Technology. Techniques et Culture 12: 151-176.

1990. Society, Nature and the Concept of Technology. Archaeological Review from Cambridge 9 (1): 5-17.

1992. Culture and the Perception of the Environment. In Bush Base: Forest Farm. E. Croll and D. Parkin editors. London: Routledge, pp. 39-56.

1993. Globes and Spheres: The Topology of Environmentalism. In Environmentalism:

The View from Anthropology. K. Milton editor. London: Routledge, pp. 31-42.

1998. Culture, Nature, Environment: Steps to an Ecology of Life. In Mind, Brain and the Environment. B. Cartledge editor. Oxford: Oxford University Press, pp. 158-180.

Leach, M. and R. Mearns (editors)

1996. The Lie of the Land: Challenging Received Wisdom on the African Environment. London: Heinemann.

McMichael, P.

1998. Development and Structural Adjustment. In Virtualism: A New Political Economy. J. G. Carrier and D. Miller editors. Oxford: Berg, pp. 95-116. 
McMinn, S. and E. Cater

1998. Tourist Typology: Observations from Belize. Annals of Tourism Research 25: 675-699.

Macnaghten, P. and J. Urry

1998. Contested Natures. London: Sage.

Milton, K.

2002. Loving Nature: Towards an Ecology of Emotion. London: Routledge. Forthcoming.

Montego Bay Marine Park

1998. Management Plan. Computer file.

Moore, M.

1993. Good Government? Introduction. IDS Bulletin 24(1): 1-6.

Nietschmann, B.

1995. Defending the Miskito Reefs with Maps and GPS. Cultural Survival Quarterly 18 (4): 34-7.

O'Callaghan, P. A., J. Woodley and K. Aiken

1988. Montego Bay Marine Park: Project Proposal for the Development of Montego Bay Marine Park, Jamaica. Typescript.

Olwig, K. F.

1980. National Parks, Tourism, and Local Development: A West Indian Case. Human Organization 39: 22-31.

Pattulo, P.

1996. Last Resorts: The Cost of Tourism in the Caribbean. Kingston: Ian Randle.

Polunin, N., I. Williams, J. Carrier, and L. Robertson

2000. Final Technical Report: Ecological and Social Impacts in Planning Caribbean Marine-Reserves. (DFID project number R6783.) TS.

Roe, E.

1991. Development Narratives, or Making the Best of Blueprint Development. World Development 19: 287-300.

Scura, L. F. and T. van't Hof

1993. The Ecology and Economics of Bonaire Marine Park. The World Bank, Environment Department, Divisional Paper No. 1993-44. Washington, DC: World Bank.

Statistical Institute of Jamaica

1996. Statistical Yearbook of Jamaica 1995. Kingston: Statistical Institute of Jamaica.

Strang, V.

1997. Uncommon Ground. Oxford: Berg.

Toye, J.

1993. Dilemmas of Development. (2nd ed.) Oxford: Basil Blackwell.

van't Hof, T.

1985. The Economic Benefits of Marine Parks and Protected Areas in the Caribbean

Region. Proceedings of the Fifth International Coral Reef Congress 6: 551-6. 


\begin{abstract}
Some recent influential work on understandings of the environment identifies what can be called a "Modern" view, which sees the environment in impersonal, objective terms, as separated from the Modern individual. That work also tends to ignore the ways that people's actions regarding their environment can be constrained by external factors and can result in a modification of people's initial views of the environment or the adoption of additional views. This article looks at some environmental activists in Jamaica to suggest that people with Modern backgrounds can have a non-Modern view of their surroundings, and to illustrate the ways that their actions regarding the environment can lead them to complicate their understandings of their surroundings.
\end{abstract}

\title{
Resumé
}

Certains travaux récents d'importance, qui s'occupent de la compréhension de l'environnement, identifient une perspective "moderne" où l'environnement est regardé en termes impersonnelles et objectif comme quelque chose séparé de l'individu moderne. Ces travaux ont aussi une tendance d'ignorer la manière dans laquelle les actions des gens envers leur environnement peuvent être contraintes par des facteurs externes et peuvent résulter dans la modification des perspectives initiales envers l'environnement et l'adoption de nouvelles perspectives. Cet article considère des activistes de Jamaïque afin de suggérer que ceux avec une perspective moderne peuvent avoir une perspective non moderne envers l'environnement. L'article illustre aussi les manières dans lesquelles les actions envers l'environnement peuvent influencer et compliquer la compréhension de l'ambiance et du milieu.

Mots clefs: Jamaïque, Montego Baie, actvisme environnementale, individu moderne, ecotourism, parc marine, pèche, néoliberalisme, perspective culturaliste.

\section{Resumen}

Cierto trabajo reciente que influye los entiendimentos del ambiente identifica lo que se puede llamar una opinión "Moderna," el cual considera el ambiente en términos impersonales objetivos, como algo separado del individuo moderno. Ese trabajo también tiene la tendencia de ignorar las maneras en que las acciones de la gente al respecto del ambiente pueden ser restrinigidas por factores externos y pueden resultar en una modificación sus opiniones iniciales o la adopción de visiónes adicionales del ambiente. Este artículo exmina algunos activistas ambientales en Jamaica y sugiere cieta gente con antecedentes modernos pueden tener una visión "tradiccional" del ambiente. Este artículo también ilustra las maneras en que las acciones de estos activistas con respecto al ambiente los puede conducir a complicar sus entiendimentos del ambiente.

Palabras claves: Jamaica, bahía de Montego, activismo ambiental, individuo moderno, ecotourism, parque marina, pesca, neoliberalism, perspectiva culturalista. 
Limits of environmental understanding: action and constraint

This page intentionally left blank 